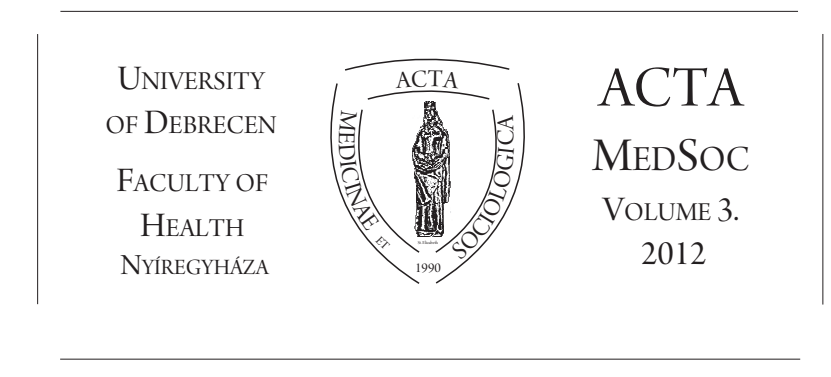

\title{
Munkaadói elégedettség-vizsgálat eredményei három megyében
}

\author{
Jóna György \\ Debreceni Egyetem, Egészségügyi Kar, \\ Alkalmazott Társadalomtudományi Tanszék \\ e-mail: jona.gyorgy@foh.unideb.hu
}

\begin{abstract}
.
In this study, we have examined the level of satisfaction of Directors of social institutions with the work carried out by the graduates of the University of Debrecen, Faculty of Health. In our survey, responses given by 138 Directors were examined. According to the survey results, the respondents are fully satisfied with the empathy and professional competence demonstrated by the graduates of the Faculty, however, the knowledge of foreign languages, the ability to work independently and the contact keeping with the other institutions remain challenges to be addressed.
\end{abstract}

DOI: $10.19055 / \mathrm{ams} .2012 .3 / 6-7 / 6$

\section{Bevezetô}

A tanulmány keretében arra keressük a választ, hogy Szabolcs-Szatmár-Bereg megye, Borsod-Abaúj-Zemplén megye és Hajdú-Bihar megye szociális intézményeinek vezetôi mennyire vannak megelégedve a Debreceni Egyetem Egészségügyi Kar alapszakon végzett vagy fóiskolai diplomával rendelkezó levelezó vagy nappali tagozaton oklevelet szerzett szociális munkások felkészültségével, szakmai tudásával és tapasztalataival; a Karon szerzett ismeretek, képességek és kompetenciák mennyire illeszkednek az adott szociális intézmény menedzsmentjének elvárásaihoz. Az adatfelvétel 2010. október és december között zajlott, a kiadásokat a Debreceni Egyetem Egészségügyi Kar Szaki Tudományos Alapja fedezte. Erre az empirikus kutatásra 
azért volt szükség, hogy a Kar - többek között - minőségbiztosítás-vizsgálat keretében információhoz jusson a munkaadók képzéssel kapcsolatos elvárásairól, melyeket a késóbbiekben figyelembe vesznek a Kar oktatói a tantárgyi programok kidolgozásánál; fontos tudni, hogy a szociális munkás alapképzésben mely részeket kell erôsíteni, milyen új elemeket kell beemelni, továbbfejleszteni, esetleg kivenni, és mely aspektusokat kell változatlanul hagyni a munkaerö-piaci elvárásoknak megfelelően.

\section{Módszer}

A vizsgálatba három megye (Szabolcs-Szatmár-Bereg megye - SZSZB megye, Borsod-Abaúj-Zemplén megye - BAZ és Hajdú-Bihar - HB megye) állami-önkormányzati, non-profit és egyházi fenntartású intézményvezetôinek véleményére voltunk kíváncsiak. A mintába a jóléti pluralizmus szerint az állami-önkormányzati, egyházi és non-profit szervezetek egyaránt bekerültek. Viszont nem kerültek olyan profitorientált szervezetek a mintavételi keretbe (bankok, kis- és középvállalkozások, multinacionális cégek, stb.), melyek társadalmi felelősségvállas jegyében szociális jellegú tevékenységet is folytatnak. E hiányosság azonban nem vagy alig érezhetően torzíthatja megszerzett adatainkat, mert a magyar szociálpolitikában elenyésző mértékben vesznek részt ezek a szervezetek.

Eredetileg Jász-Nagykun-Szolnok megyét is bevontuk a kutatásba, formális és informális ismereteink szerint ezekben a megyékben is több végzett hallgatónk helyezkedett el. Ám ebból a megyéból nagyon kevés kitöltött kérdőívet kaptunk vissza, ezek értékelhetetlenekké váltak, ezért kihagytuk ezeket a vizsgálatból. A három megyében található szervezetek listáját a Nemzeti Foglalkoztatási Szolgálat szociális regiszteréból szereztük meg. Az alapsokaság igen nagyszámú volt, ezért egyszerú mintavételi eljárással (simple random sampling) mintavételi keretet alkottunk. Összesen 400 darab kérdôívet és válaszborítékot küldtünk el postán a kiválogatott címekre, az intézményigazgatók ebból 152-t küldtek vissza, 138-at találtunk kiértékelhetőnek. Mintavételi eljárásra azért van szükség, mert nincs lehetôség a teljes sokaságot megkérdezni. A populációból tehát mintát kell venni, ami majdnem ugyanúgy (néhány, általában 95\%-os pontossággal) prezentálja a teljes sokaságot. A minta reprezentativitását a mintavételi eljárás határozza meg, melynek több típusát lehet kiemelni. A reprezentativitás feltétele, hogy a vizsgált populáció minden egyes tagjának azonos valószínúséggel kell bekerülnie a mintavételi keretbe. Ennek szigorú betartásával a minta reprezentativitása elérhető. ${ }^{1}$ Azt a mintavételi eljárást célszerú alkalmazni, mely a kutatás témájával és logikájával összhangban van.

\footnotetext{
${ }^{1}$ Ez természetesen az elméleti feltétel, ennek gyakorlati megvalósítása több akadályba ütközik, pl.: nem ismerjük pontosan a teljes populáció minden attribútumát, ezért a viszonyítás, vagy a mintavételi keret létrehozása sem lehet teljesen pontos. A kutatói intuíció, tapasztalat szerint, nincs tökéletesen reprezentatív minta, ha egy minta 3 vagy 4 aspektusból reprezentatív, akkor már az használható.
} 
Az intézmények területi eloszlása plurális, követi a térség szociális differenciáltságát. Megyeszékhelyen található az intézmények közel egyötöde, majdnem egyharmada városban, több mint fele falvakban létesült. A vizsgálatba bevont intézményeket kis részét (4,14\%-át) két évnél korábban alapították, teljesen egyenló arányban hozták létre a 2-5 év (19,56\%) és 6-10 év (19,56\%) közötti szervezeteket, a fennmaradókat 10 évnél is régebben létesítették. Legkorábban az államiönkormányzati, majd a civil és egyházi fenntartású intézményeket alapították. Az intézmények átlagéletkora 14 év volt.

A mintavételi keretben található intézmények háromnegyede szociális alapszolgáltatást, a fennmaradó egynegyede szociális szakosított ellátásokat nyújt.

$\mathrm{Az}$ adatsor elektronikus rögzítése és feldolgozása az SPSS 8.0 statisztikai programcsomag segítségével történt.

\section{A vizsgálat elméleti forrásai}

A Bolognai-folyamat magyarországi kibontakozásával az oktatás, ezen belül a felsőoktatás, és a munkaerôpiac összehangolása, kongruenciája kiemelt fontosságú feladat (Hrubos 2010, 2011a, 2011b). A Bolognai-folyamat hangsúlyozza a gyakorlati ismeretek és képességek átadását, valamint a munkaerô-piaci igények figyelembevételét a felsôoktatási rendszerben (Temesi 2007). A munkaadói oldal egyre eróteljesebben ad hangot annak az igényének, hogy a felsőoktatásban a klasszikus akadémiai tudás felé kell kerekednie a gyakorlati ismereteknek, képességeknek és tapasztalatoknak. Sokkal inkább naprakész tudással rendelkezó, alapos felkészültségû diplomásokra van szüksége a piacnak és nem filozófiai elmélyültséggel bíró munkavállalókra. Természetesen mindkét tudástípusra elengedhetetlenül szükség van, mindkettő kell, ám hangsúlybeli eltolódásokkal a piac által támasztott kompetenciák javára. Ez a szemléletváltás nem kerülte el a szociális munkás képzést sem Magyarországon. Mielőtt az empirikus felmérés adatait elemeznénk, röviden nézzük meg, milyen elônyei és hátrányai lehetnek (vannak) ennek a hangsúlyeltolódásnak.

Az 1950-es évek folyamán fogalmazódtak meg elsóként igazán differenciáltan a felsôoktatás piacosítása elleni érvek - ezt humboldti teóriaként vált ismertté (Hrubos 2012). A humboldti filozófiák interpretációja során Habermas (1969) kifejti, hogy a felsôoktatási intézményeknek egyik fontos funkciója a tudományos diszciplínák integrált átadása, és annak „töredezettség mentesítése”. Csak egy komplex, egésszé szerveződött akadémiai ismerethalmaz elsajátítása révén értheti meg az egyén adekvát formában a természet- és a társadalomtudományos paradigmákat. Az egyetem feladata, hogy tudományos tudást nyújtson, és ne specializációk során végletekig (néha már nevetségességig) professzionalizált és differenciált ismereteket. A második jellemzóje, hogy az elméleti tudást szintetizálni kell az empirikus kutatásokkal, csak ezen az úton szerezhető meg új, alkalmazható komplex tudás lásd errôl Robert Merton (2008) középszintú elméletét. A harmadik sajátossága az, hogy a tanulás és a tanítás szabadságát biztosítsa a felsőoktatási intézmény hallgatóinak (például az oktatóknak a szabad témaválasztást, a hallgatóknak pedig az 
óraválasztást) (Polónyi-Tímár 2001). A humboldti tézisek elutasítják a munkaerôpiaci igényeknek való megfelelést, úgy vélik, hogy helytelen, ha a piac határozza meg a felsőoktatási folyamatokat. Ugyanis, a "modern tudomány olyan ismereteket nyújt, amelyek technikailag hasznosíthatók. De arra a kérdésre nem tud válaszolni, hogy hogyan éljünk. Ez a kérdés számára nem érdekes. A gyakorlathoz való technikai viszonyulás a hogyan éljünk kérdéstől való eltávolodáshoz vezet." (Weiss 2000: 45) Látható, hogy a humboldti filozófiák is tartalmaznak olyan komponenseket, melyek a technológiai ismeretek képtelenek átadni.

Ezzel a rövid kitérôvel csupán jelezni kívántuk, hogy az általunk készített adatfelvételek nem minden térségben és társadalomtudományi diszciplínában akceptálhatók.

\section{Kutatási eredmények}

\section{A képzés erôsségei}

A bevont intézmények majdnem háromnegyede állami, önkormányzati fenntartású, civil szervezetek képezik közel egyharmadát, és az egyházi finanszírozású szervezetek aránya nem éri el a 3 százalékot. (A szociális szektor finanszírozásában történô változások napjainkra minden bizonnyal átrendezték ezeket az arányokat.)

A szociális szakma - csakúgy, mint egy sor más professzió - elnóiesedett. Ez vezetôi szinten is megfigyelhető: a megkérdezett intézményigazgatók kicsivel több mint 10\%-a volt férfi, a többi nô. A megyék között az ilyen típusú nemi eloszlás teljesen kiegyenlítettnek mutatkozott. Ha fenntartó szerint elemezzük a nemi viszonyokat, akkor a kép plurálisabb: az állami-önkormányzati szervezetek alkalmaznak inkább nôi vezetőket (90\%-a volt nô), a civil szervezetek majdnem ötödénél férfi töltött be vezetői pozíciót, egyházi fenntartású intézményben pedig kizárólag nô volt megtalálható.

Nézzük meg azt, hogy a munkaadói oldal a Karon végzett munkavállalók mely képességeivel van igazán megelégedve. Ezt Likert-skálával mértük (Babbie 1996). Eszerint, a munkavállalóra vonatkozó kijelentéseket az intézményvezetônek 1-tôl 5ig terjedő skálán kellett értékelni. Az értékelés az iskolai osztályzással volt azonos, 1-es a legrosszabb, 5-ös a legjobb értékelésnek minôsült.

A munkáltatók leginkább a szakmai alapok stabilitásával voltak megelégedve, véleményük szerint olyan szakmai, professzionális tudás birtokában hagyják el a szociális munkás hallgatók a Kart, amely kellóen felkészíti óket a munkaerő-piacon való elhelyezkedésre. Fôként SZSZB megye és HB megyében értek el jó eredményt a DE EK-n végzett munkavállalók, ám BAZ megyében alulteljesítettek a munkaadók szerint. Területi bontásban elemezve azt tapasztalhatjuk, hogy a megyeszékhelyen és falvakban lévô intézetigazgatók mondták, hogy a legstabilabb szakmai alapokkal rendelkeznek munkatársaik, ám a városi vezetók ebból a szempontból már kissé rosszabb értékelést adtak. Ha fenntartó szerinti értékelést vizsgáljuk, akkor a legjobb értékelést az önkormányzati dolgozók kapták, majd a civilek következtek, a sort az egyházi intézményben dolgozók zárták. 
A menedzsment hasonlóan jónak minősítette a munkavállalóknak azt a képességét, mellyel további szociális- és más társintézményekkel a kapcsolatot alakítják ki. Jellemző, hogy könnyen, jó munkaviszonyt tudnak létrehozni más szociális intézmény munkatársaival, nyitottak, ám ezt a munkakapcsolatot hosszú távon már nem igazán tudják fenntartani, ápolni. Hiányzik vagy hiányos az a képességük, hogy a jó szakmai, illetve emberi viszonyokat stratégiailag meg tudjanak órizni. Ezzel a BAZ megyei vezetők találkoztak leggyakrabban, legritkábban a SZSZB és a HB megyeiek. Kiemelkedôen jó képességek sorában jelölték meg az intézményvezetók a DE EK-n végzettek empátiáját és az alkalmazkodó-képességét is, mely a munkatársak és a kliensek irányába egyformán megnyilvánul. E tekintetben nem mutatható ki megyei eltérés egyet kivéve: igazán empatikus munkatársakról leginkább HB megyei igazgatók számoltak be. Települési viszonyok viszont ennél komplexebbek voltak. Szignifikáns korreláció tapasztalható a település nagysága és az empátia között, minél nagyobb területú települést (megyeszékhely) vizsgálunk annál nagyobb az empátia, minél kisebb települést (falu) elemzünk, annál kisebb empatikus készségú munkavállalóval találkozhatunk az intézményigazgatók szerint. Fenntartó szerinti aspektusból egyértelmúen az egyházi szervezetek járnak az élen az empatikus magatartásforma alapján.

Közepesen jónak ítélték meg az elméleti, lexikális tudás gyakorlatba való átültetésének képességét, a teoretikus ismeretekeket nem minden esetben tudják a gyakorlatban megvalósítani. A hiányos konverziós képességek kedvezótlen hatásai a team-munkában is kimutathatók, ám az intézményvezetôk szerint a Karon végzett munkatársaik hamar megtanulják, miként lehet a gyakorlati életben alkalmazni az elméleti tudást. Ez a gyors tanulás azonban csak akkor tud gyakorlattá válni, ha vezetôi irányítás alatt állnak a végzett hallgatók; az önálló munkavégzésre való képességük még hiányos.

A társadalmi-gazdasági és szociális problémákat átfogóan, a maguk komplexitásában képesek értelmezni, a társadalmi valóságot és változásokat tágabb összefüggésrendszerben megértik. Ha szükség van rá, ezeket a szociális jellegú átalakulásokat érthetően, egyértelmúen el tudják magyarázni a klienseknek is.

Az elégedettségi indikátorok már kicsit kedvezôtlenebbek a folyamatos munkavégzés tekintetében, de még mindig igen jónak mondhatók. Problémamegoldó képességük viszonylag kevés tapasztalat alapján formálódott, ezt azonban a gyakorlatorientált képzés meg tudja oldani. Ez egybecseng az előzô fejezetbe leírtakkal, miszerint a felsôoktatás szinte minden egyes szakaszán ez a munkaadói igény kimutatható. A megkérdezett intézményigazgatók nyitott kérdésekre válaszolva kifejtették, hogy a magasabb gyakorlati óraszámban végzett hallgatók problémaérzékenysége kifinomultabb azokhoz képest, akik kevesebb gyakorlati terepet rövidebb ideig látogattak. A gyakorlati képzés és a probléma-érzékenység között szignifikáns kapcsolat áll fenn: a gyakorlati órák számának emelése elôsegítené a munkaerő-piaci elvárások és a képzés szinkronba hozását. A munkaadók jónak ítélték még a Karon végzettek precíz munkavégzését, az új ismeretek gyors elsajátítását, reális helyzetértékelésüket, valamint az eredményközpontú szemléletet. 
Látható az 1. táblázatból, hogy a rangsorban hátrébb állnak a gyakorlati készségekkel való elégedettség indikátorai, úgymint a szervezókézség, a problémákra való adekvát reakció, rendszerszerú gondolkodás és alkalmazása, valamint a munkabírás. Legutolsó helyen a számítógépes jártasság, az alapfokú informatikai tudás és a módszeres munkavégzés szerepel, melyre a képzésben majd érdemes nagyobb hangsúlyt fektetni.

\begin{tabular}{|l|c|}
\hline Állítás & Érték \\
\hline Szakmai, elméleti alapok & 4,6757 \\
\hline Más intézményekkel való együttmúködés & 4,6216 \\
\hline Mások megértése & 4,6216 \\
\hline Társintézményekkel való kapcsolattartás & 4,5946 \\
\hline Nyitottság munkatársak felé & 4,5405 \\
\hline Szükségletfelmérés készítése & 4,4595 \\
\hline Alkalmazkodóképesség & 4,4054 \\
\hline Elmélet és gyakorlat együttes alkalmazása & 4,4054 \\
\hline Csapatmunka & 4,3784 \\
\hline Információnyújtás & 4,3243 \\
\hline Társadalmi beágyazottságában & \\
értelmezi a szociális problémát & 4,3243 \\
\hline Társadalom valódi múködését felismeri & 4,3243 \\
\hline Egyértelmú kifejezóképesség & 4,2973 \\
\hline Problémamegoldó modell alkalmazása & 4,2973 \\
\hline Precíz munkavégzés & 4,2973 \\
\hline Tanulási képesség & 4,2973 \\
\hline Reális & 4,2703 \\
\hline Gyakorlati jártasság & 4,2703 \\
\hline Eredményközpontú szemlélet & 4,2703 \\
\hline Szervezóképesség & 4,2432 \\
\hline Nagy munkabírás & 4,2432 \\
\hline Elemzó képesség & 4,2432 \\
\hline Problémaelemzó képesség & 4,2432 \\
\hline Pontosság & 4,2432 \\
\hline Realitásérzék & 4,2432 \\
\hline Felismeri a jó megoldásokat & 4,2162 \\
\hline Ujj készségek elsajátítása & 4,2162 \\
\hline Rendszerezó képesség & 4,2162 \\
\hline Információfeldolgozás & 4,1892 \\
\hline Számítógépes jártasság & \\
\hline Módszeres munkavégzés & \\
\hline
\end{tabular}

1. táblázat A képzés erôsségei az intézményigazgatók szerint. 


\section{Hiányosságok a képzésben}

Ebben részben azt mutatjuk be, hogy az intézményigazgatók mely tudáselemeket, készségeket és képességeket hiányolják a Karon végzett szociális munkásoknál. A 2. táblázatból egyértelmúen kiderül, hogy a legnagyobb hiányosság az idegennyelvtudásban van: 5-ös skálán ezt 3,2-re értékelték. Ez arra enged következtetni, hogy a munkaadói oldal egyértelmú elvárása a végzettek idegennyelv-tudása, ezt az alapképzésben résztvevókkel szembeni alapvető feltételként fogalmazzák meg. A diploma és a nyelvismeret összekapcsolása piaci megközelítésben akceptálható.

Az idegennyelv-ismeret BAZ megyében volt a legrosszabb, majd SZSZB megyében, a legjobb eredmény HB megyében volt. Nem várt eredmény, hogy a település nagyságával fordítottan arányos elégedettségi arányt tapasztaltunk: a falusi intézményigazgatók voltak leginkább megelégedve a DE EK-n végzett munkavállalójuk nyelvi kompetenciájával, majd a városiak, legrosszabb mutatóval a megyeszékhelyen dolgozók zártak. Fenntartó szerinti elemzésben egyértelmú az önkormányzati szektorban érezhetô hiányosságként jelenik meg ez a kompetencia, az egyháziaknál is tapasztalható (az esetek majdnem egytizedénél kaptunk ilyen választ), a civil szférában pedig a legalacsonyabb mértékben jelent problémát az idegennyelvtudásának hiánya. A valóság ettôl összetettebb. Többváltozós vizsgálat alapján megállapíthatjuk, hogy fóként a 2-3 éve létrejött civil szervezeteknél jelent ez kihívást, mert ezek forrásaik bizonyos részét nemzetközi, Európai Uniós pályázatokból nyerik. Ezen pályázatok megírásához elengedhetetlen a magas színvonalú angol (néha német) nyelvtudás. Ki kell emelni, hogy az állami, illetve önkormányzati intézmények kevésbé panaszkodnak a nyelvtudás hiányosságaira, ám ők ezt beiskolázással próbálják és tudják megoldani; a forráshiány pótlásához humán eróforrásfejlesztésbe invesztálnak. Más intézmények inkább pályázatírókat fogadnak, ez gyorsabb megoldást jelent. A 3 évnél régebben alapított civil szervezetekben a nyelvi kompetenciák nem jelennek meg ennyire szignifikánsan, mint az ettől fiatalabb civil szervezeteknél. Ennek oka az, hogy ott sikerült az idegennyelv-tudást pótolni olyan munkavállalókkal, akik jól beszélnek és írnak angolul. Röviden, az idegennyelv-oktatásra a jövóben kiemelt figyelmet kell szentelni a DE EK-n.

Az intézetigazgatók szerint komoly fejlesztést igényel a menedzsment tantárgy oktatása, elméleti és gyakorlati vonatkozásban is. A képzésból kikerülókre jellemzô, hogy szociális intézményt még középvezetői szinten is nehézkesen irányítanak, nem rendelkeznek megfelelő szintû vezetôi előképzettséggel. Ez alól csak azok képeznek kivételt, akik már korábban is vezetô beosztásban voltak. A megkérdezettek zöme vezetôi státuszba csak szigorú feltételekkel engedné a DE EK-n végzett szociális munkásokat. A menedzsment képzéssel legjobban a HB megyei, majd a SZSZB megyei, végül a BAZ megyei intézmények voltak elégedettek. A civil és egyházi szervezetek igazán jónak, ám az állami-önkormányzati intézmények kevésbé elfogadhatónak minősítették a vezetői képzést. (Csak zárójelben jegyezzük meg, hogy nappali tagozaton végzett hallgatókkal kapcsolatos véleményeket is elemeztük, az ô esetükben talán irracionális volna túlzott menedzsment képességeket feltételezni, hiszen a szociális munkás BA képzésben a menedzsment feladatok megoldására nem 
koncentrálnak. A realitás talaján maradva: nem minden esetben múködóképes az, ha egy 22-23 éves személy áll egy szociális intézmény élén. Természetesen vannak kivételek.)

Mint látható, nem sokkal jobb a helyzet a stressztưrés tekintetében, a munkahelyi stressz kezelése és feldolgozása (coping) komoly kihívást jelent (Pikó 2002). Hasonló problémák forrása a meglévő intézményrendszer fejlesztése is, amihez szervesen kapcsolódik az újítási képesség, kreativitás alacsony foka. Itt egy érdekes tényezôre szeretnénk a figyelmet felhívni: láttuk az előzôekben, hogy a Karról kikerült hallgatók egyik jó képessége közé sorolták azt, hogy nyitottak az új ismeretekre, azonban az újítási képességek vonatkozásában már kihívásokkal küzdenek. Ez azt jelenti, hogy az elméleti befogadó-készségük jó, ám a teoretikus részek gyakorlati megvalósítása akadályokba ütközik. Az innovációra fogékonyak, de gyakorlatba alig, vagy csak nagy nehézségek árán hosszú idô alatt tudják ezeket adaptálni; kombinációs képességeik is fejlesztésre szorulnak.

A megkérdezettek kifejtették, hogy újabb szervezetek létrehozásának folyamatába a Karon végzetteket ritkán vonják be, mert új szociális koncepciók kidolgozásában alulteljesítenek és az ezzel járó elemzések elkészítése is gyakran gondot okoz. Területi aspektusból vizsgálva azt mondhatjuk, hogy az előzóekkel szemben a trend itt megfordul: a HB és a SZSZB megyei intézmények elégedetlenek, míg a BAZ megyeiek igen jónak minôsítették a DE EK-n végzett munkavállalók szervezetfejlesztéssel kapcsolatos ismereteit. A település nagyságával arányos az elégedettségi arány: minél nagyobb települést vizsgálunk, annál elégedettebbek a szervezetfejlesztéssel összefüggố tapasztalatokkal, kompetenciákkal, és fordítva.

Sokat javít a helyzeten az, ha olyan tevékenységek elvégzését bízzák rájuk, melyek vezetôi irányítása alatt folynak, mint például a gyakorlatias feladatértelmezés, tanácsadói képesség, áttekintő képesség és a számszerűsítési képesség. Önálló munkát hatékonyan akkor tudnak végezni, ha valaki irányítása alatt állnak, azonban az eredményesség rögtön csökken, ha vezetői vagy középvezetői státuszba kerülnek. Team-munkában akkor sikeresek, ha nem vezetóként dolgoznak, önálló munkavégzésük további fejlesztésre szorul, már a képzés ideje alatt.

A megkérdezettek majdnem 70 százaléka vélte úgy, hogy kollégáinak továbbképzésre van szüksége, a fennmaradó egyharmad szerint még nem jött el a beiskolázások ideje. Megyei szintû bontásban megállapítható, hogy hasonló arányú az intézményigazgatók véleménye. Összetett nexus áll fenn településméret alapján: a falvakban múködố intézményvezetôk szerint 63\%-ban, a városiaknál 81\%-ban, megyeszékhelyen 71\%-ban van erre szükség.

Területileg a továbbképzés típusáról megoszlanak a vélemények: mesterképzést leginkább a HB megyeiek, majd a SZSZB megyeiek preferálják, legalacsonyabb mértékben a BAZ megyeiek választanák. Egységesek a vélemények a szakirányú továbbképzési szakok favorizálása tekintetében, a válaszok közel 60\%-ában ezt a képzési formát tartják szükségesnek a továbbképzés során. Ebból az derül ki, hogy a szociális menedzsment ebben a három megyében inkább specializált, mélyebb és tapasztalatokon nyugvó ismeretek elsajátítását hangsúlyozza munkatársainak. 
Meglehetősen magas volt ennél a kérdésnél a látencia, a válaszadók közel egynegyede pedig nem válaszolt erre a kérdésre, melynek okát nem ismerjük. Fóként az egyházi szociális szervezetek menedzsmentje részesíti előnyben ezt a képzési formát. Az önkormányzati és civil szféra vezető aktorainak közel fele a mesterképzést, másik fele a szakirányú továbbképzést választaná alkalmazottainak.

A SZSZB megyei igazgatóknak csupán a fele javasolná a DE EK-t továbbtanulás céljából munkatársainak, a HB és BAZ megyei igazgatóknak majdnem a kétharmada volt ezen a véleményen. A falvakban és megyében múködô szociális intézmények vezetőinek kicsivel több mint fele, a városi vezetőknek közel kétharmada részesítené a DE EK-t elônyben a továbbképzésnél. Ez az arány kimagasló a civil szervezetek esetében.

\begin{tabular}{|l|c|}
\hline Állítás & Érték \\
\hline Idegennyelv-tudás & 3,2703 \\
\hline Menedzsment ismeretek és képességek & 3,4176 \\
\hline Absztrakt gondolkodás & 3,5135 \\
\hline Stressztûrés & 3,6216 \\
\hline Intézményrendszer fejlesztése & 3,8378 \\
\hline Újítási képesség & 3,8378 \\
\hline Szociális stratégiák kidolgozása & 3,8919 \\
\hline Kombinációs képesség & 3,8919 \\
\hline Ellenôrzóképesség & 3,9459 \\
\hline Irásos szakmai anyagok készítése & 3,9730 \\
\hline Célirányosság & 4,0270 \\
\hline Analitikus szemlélet & 4,0541 \\
\hline Lehetôségek észrevétele & 4,0811 \\
\hline Számszerúsítési képesség & 4,1081 \\
\hline Alaposság & 4,1351 \\
\hline Gyakorlatias feladatértelmezés & 4,1351 \\
\hline Áttekintő képesség & 4,1622 \\
\hline Tanácsadói képesség & 4,1622 \\
\hline
\end{tabular}

2. táblázat A képzés hiányosságai az intézményigazgatók szerint. 


\section{Összegzés}

Mindent összevetve, a Kar szociális munkás alapképzésével a megkérdezett szociális intézményigazgatók meg voltak elégedve. A Kar olyan szakmai-elméleti alapokkal, a más intézmények iránti nyitottsággal, fejlett empátiával és alkalmazkodóképességgel bocsátja ki a hallgatóit, mely fontos értékteremtô funkciót lát el a munkaerő-piacon. Ezek megtartása továbbra is nélkülözhetetlen. Szociális szakmai körökben jó híre van a Kar szakirányú továbbképzési szakjainak, amit az is alátámaszt, hogy ilyen speciális, elmélyült tudást és tapasztalatot nyújtó, viszonylag rövid ideig tartó képzésbe vonnák be legszívesebben munkatársaikat a menedzsment tagjai.

A DE EK-n végzett munkatársaikról a legjobb értékelést adták a HB megyei intézményigazgatók, majd a SZSZB megyeiek, a legrosszabb eredményekról pedig a BAZ megyeiek számoltak be.

A képzés leggyengébb láncszemeként az idegennyelv-oktatást jelölték meg, ennek megerôsítésére nagyobb hangsúlyt kell helyezni. Továbbá, a menedzsment elméleti és gyakorlati ismereteinek átadásának fejlesztése, valamint az önálló munkavégzés megtanítása lenne igazán fontos az intézményvezetók szerint. Mindezek adekvát kezelésével a hallgatók (potenciális munkavállalók) könnyebben megtalálják helyüket a társadalmi munkamegosztásban, gyorsabban el tudnak helyezkedni a munkaerô-piacon.

\section{Irodalom}

- Babbie, Earl (1996): A társadalomtudományi kutatás gyakorlata. Budapest: Balassi Kiadó.

- Habermas, Jürgen (1969): Az iskolai és a fóiskolai képzés hatása a diákok politikai tudatára. In: Huszár Tibor - Sükösd Mihály (szerk.): Ifjúságszociológia. Budapest: Közgazdasági és Jogi Kiadó. 252-263.

- Hrubos Ildikó (2010): Bologna folytatóik. Educatio, 1: 19-33.

- Hrubos Ildikó (2011a): The Changing Role of Universities in our Society. Society and Economy, 2: 347-360.

- Hrubos Ildikó (2011b): Örök felsőoktatási érték - változó hangsúlyokkal. $E d u$ catio, 2: 208-219.

- Hrubos Ildikó (2012): Kíméletlen verseny - bóvülő missziók a felsôoktatásban. Educatio, 2: 223-232.

- Merton, Robert (2008): Társadalmi rendszer és struktúra. Budapest, Akadémiai Kiadó.

- Pikó Bettina (2002): Egészségszociológia. Budapest: Új Mandátum Kiadó. 
- Polónyi István - Tímár János (2001): Tudásgyár vagy papírgyár. Budapest: Új Mandátum Kiadó.

- Temesi József (2007): Felsôoktatási kreditrendszer, a képesítési keretrendszer és az ekvivalencia összefüggései. Educatio, 2: 217-231.

- Weiss János (2000): Tizenkét előadás a Frankfurti Iskoláról a diákmozgalmakról. Budapest: Áron Kiadó.

Jóna György, fôiskolai adjunktus

Debreceni Egyetem, Egészségügyi Kar, Nyíregyháza, 4400, Sóstói út 2-4. 